\title{
Temperature increases in primary teeth pulp chamber during polymerization of glass ionomer-based restorative materials
}

\section{Purpose}

To evaluate the temperature changes in primary teeth pulp chambers of different dentin thicknesses during polymerization of four glass ionomer-based restorative materials.

\section{Materials and Methods \\ Eighty extracted, caries-free, primary molars were prepared as standardized Class I occlusal cavities with dentin thicknesses of $1 \mathrm{~mm}$ and $2 \mathrm{~mm}$. Four glass ionomer- based restorative materials, Dyract XP, Photac Fil Quick Aplicap, Fuji II LC, and GCP Glass Fill, were placed in the cavities and cured with two light-curing units. Temperature increases (initial temperature, $37^{\circ} \mathrm{C}$ ) in the pulp chamber during polymerization were recorded by a J-type thermocouple in a pulpal microcirculation set-up. The data were analyzed with Variance analyses and Tukey tests.}

\section{Results}

The temperatures recorded in samples with dentin thicknesses of $1 \mathrm{~mm}$ and 2 $\mathrm{mm}$ exhibited statistically significant differences $(p<0.05)$. The GCP Glass Fill group exhibited the highest temperature increases for both dentin thicknesses $(p<0.05)$. The other groups were not statistically different but the Dyract XP group exhibited the least temperature change.

\section{Conclusion}

The highest temperature changes were observed for $1 \mathrm{~mm}$ dentin thickness. All temperature increases during polymerizations and setting reactions were lower than the corresponding critical values $5.5^{\circ} \mathrm{C}$.

Keywords: Glass carbomer, Glass ionomer, Primary teeth, Temperature increase, Pulp

\section{Introduction}

Dental pulp forms the core of the tooth and consists of live connective tissues in a highly vascularized structure. Given the fragile nature of pulp tissue, any clinical restorative treatment performed near the pulp chamber may affect pulp vitality. A subject of particular concern is the heat generated during restorative processes, i.e, intrapulpal temperature increase (1). A variety of factors may contribute to this phenomenon, including cavity preparation procedures, bleaching of teeth, laser applications, polishing dental materials, and polymerization of light-curing materials (2). Temperature increase during polymerization may be caused by two main factors: heat produced by the light source during polymerization of materials, and the exothermic polymerization of materials. A number of additional factors, such as light intensity of the light source, remaining dentin thickness, composition of restorative materials, distance between light source and material surface, light source position, and exposure time, can affect the temperature of the pulp chamber during polymerization (3).

\author{
Çiğdem Büyükkok ${ }^{1}$ (D, \\ Arife Kaptan'
}

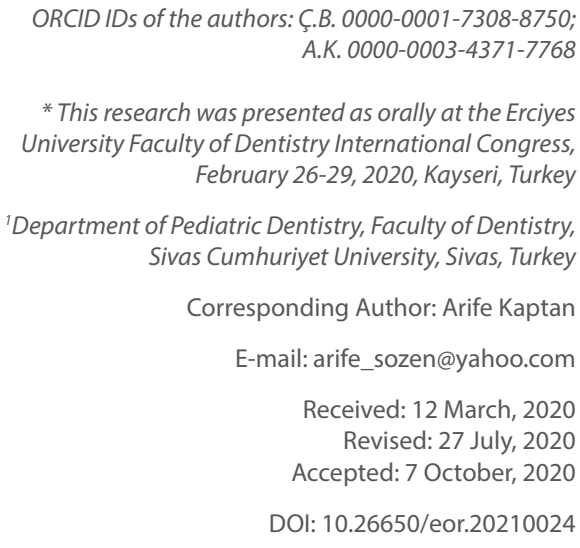


Zach and Cohen (4) reported that an increase of merely $5.5^{\circ} \mathrm{C}$ in intrapulpal temperature for a duration of $10 \mathrm{~s}$ could cause serious histological changes to the pulp tissues, including protoplasm coagulation, expansion of liquid present in dentinal tubules, vascular injuries, and tissue necrosis.

The behavior of dental tissue in response to thermal stimuli depends on the physiological characteristics of the tooth. Primary teeth have larger dentin tubule structures than those of permanent teeth, which increases the permeability of primary teeth and causes them to be more easily affected by external stimuli (5). Dentin and its geometric structure additionally play an important role in the increase of heat. When the remaining dentin thickness decreases, the pulp becomes more sensitive to heat increase (6).

Glass ionomer cements (GICs) have been successfully used in pediatric patients owing to their chemical bonds to enamel and dentin, ability to release fluoride, similarity with dentin in terms of thermal expansion, and high remineralization capacity (7-9). However, GICs have some disadvantages, such as lower resistance, marginal deficiencies, and decreased hardness in the presence of moisture contamination and increased dissolution. Various formulas and modifications have been developed to overcome the deficiencies of conventional GICs (10).

Glass carbomer (GC) is a glass ionomer-based restorative material. Glass carbomer is distinguished from glass ionomer by its nanosized powder particles and fluorapatite crystals. It's claimed that GC exhibits excellent clinical performance and is superior to many traditional and high-viscosity GIC filling materials because of its nano sized powder particles and fluoride-hydroxyapatite structure (11). The clinical application of GC is similar to that of conventional GICs except that heat application $\left(60^{\circ} \mathrm{C}, 60 \mathrm{~s}\right)$ with a special thermocure lamp is recommended during the setting reaction of GC. Furthermore, GCs do not contain resins, monomers, and BPA, which are considered as toxic (12).

The aim of this study was to evaluate temperature changes in primary teeth pulp chambers with different dentin thicknesses during polymerization of a GC (GCP Glass Fill), two different resin-modified glass ionomer cements (RMGICs) (Fuji II LC, and Photac Fil Quick Aplicap), and a compomer (Dyract XP) which were frequently used in pediatric dentistry. The hypotheses of this study were as follows: (1) there would be no intrapulpal thermal changes when using a GC, two RMGICs, and a compomer, and (2) the difference in dentin thicknesses would have effect on intrapulpal thermal changes.

\section{Materials and Methods}

Ethical approval was obtained from the Health Ethics Committee of Cumhuriyet University, Sivas, Turkey (ID: 201707/05). The materials and light-curing units (LCUs) used in the study are shown in Tables 1 and 2.

\section{Sample size calculation and experimental groups}

Sample size was calculated using a sample size calculator (Sample Size Determination in Health Studies, World Health Organization) as follows: power at $90 \%, \alpha$ at $5 \%, \beta$ at $10 \%$, and the sample size was determined to be 20 teeth in each group. Thus, a total of 80 extracted primary molar teeth was required for the study.
Table 1. Materials used the study

\begin{tabular}{|c|c|c|c|c|}
\hline Product & Type & Compositions & $\begin{array}{l}\text { Filler ratio } \\
\text { (weight) }\end{array}$ & Manufacturer \\
\hline $\begin{array}{l}\text { Dyract } \\
\text { XP }\end{array}$ & Compomer & $\begin{array}{l}\text { UDMA, TCB, } \\
\text { TEGDMA, strontium- } \\
\text { alumino-sodium- } \\
\text { fluoro-phosphor- } \\
\text { silicate glass }\end{array}$ & $\% 73$ & $\begin{array}{l}\text { Dentsplay, } \\
\text { Germany }\end{array}$ \\
\hline $\begin{array}{l}\text { Photac- } \\
\text { Fil } \\
\text { Quick } \\
\text { Aplicap }\end{array}$ & $\begin{array}{l}\text { Resin- } \\
\text { modified } \\
\text { glass } \\
\text { ionomers }\end{array}$ & $\begin{array}{c}\text { Poly(co-acrylic } \\
\text { acid/maleic acid), } \\
\text { HEMA, hydrophilic } \\
\text { monomers, fluoro- } \\
\text { alumino-silicate } \\
\text { glass }\end{array}$ & $\% 76$ & $\begin{array}{l}\text { ESPE GmbH, } \\
\text { Seefeld, } \\
\text { Germany }\end{array}$ \\
\hline $\begin{array}{l}\text { GC Fuji } \\
\text { II LC }\end{array}$ & $\begin{array}{l}\text { Resin- } \\
\text { modified } \\
\text { glass } \\
\text { ionomers }\end{array}$ & $\begin{array}{l}\text { HEMA, TEGDMA, } \\
\text { poly acyrilic acid, } \\
\text { fluoro-alumino- } \\
\text { silicate glass }\end{array}$ & $\% 58$ & $\begin{array}{c}\text { GC Corp., Tokyo, } \\
\text { Japan }\end{array}$ \\
\hline $\begin{array}{l}\text { GCP } \\
\text { Glass } \\
\text { Fill }\end{array}$ & $\begin{array}{c}\text { Glass } \\
\text { carbomer }\end{array}$ & $\begin{array}{l}\text { fluoroaluminosilicate } \\
\text { glass, apatite, } \\
\text { polyacids }\end{array}$ & & $\begin{array}{l}\text { GCP Dental, } \\
\text { Ridderkerk, } \\
\text { Netherlands }\end{array}$ \\
\hline \multicolumn{5}{|c|}{$\begin{array}{l}\text { UDMA, urethane dimethacrylate; TCB, a reaction product ofbutane } \\
\text { tetracarboxylic acid and hydroxyl methyl methacrylate; TEGDMA, } \\
\text { triethylene glycol dimethacrylate; HEMA, hydroxyl ethyl methacrylate }\end{array}$} \\
\hline
\end{tabular}

Table 2. Light-curing units used the study

\begin{tabular}{lcc} 
LCU & Manufacturer & $\begin{array}{c}\text { Light } \\
\text { intensity }\end{array}$ \\
\hline $\begin{array}{l}\text { Valo LED (standart } \\
\text { mod) }\end{array}$ & $\begin{array}{c}\text { Ultradent, South Jordan, } \\
\text { USA }\end{array}$ & $1000 \mathrm{~mW} / \mathrm{cm}^{2}$ \\
\hline
\end{tabular}

Based on the restorative materials used in the study, the 80 teeth were randomly divided into four main groups of 20 teeth each. Each group was divided into two subgroups (dentin thicknesses of $1 \mathrm{~mm}$ and $2 \mathrm{~mm})(\mathrm{n}=10)$. The experimental groups are shown in Table 3.

Table 3. Study design

\begin{tabular}{lccc} 
Groups & $\begin{array}{c}\text { Dentin } \\
\text { thickness }\end{array}$ & $\mathbf{n}$ & LCUs/curing times \\
$\begin{array}{l}\text { GRUP I } \\
\text { (Dyract XP) }\end{array}$ & $1 \mathrm{~mm}$ & 10 & VALO LED/20 sn \\
\hline $\begin{array}{l}\text { GRUP II } \\
\text { (Photac- }\end{array}$ & $2 \mathrm{~mm}$ & 10 & VALO LED/20 sn \\
$\begin{array}{l}\text { Fil Quick } \\
\text { Aplicap) }\end{array}$ & $2 \mathrm{~mm}$ & 10 & VALO LED/20 sn \\
$\begin{array}{l}\text { GRUP III } \\
\text { (Fuji II LC) }\end{array}$ & $1 \mathrm{~mm}$ & 10 & VALO LED/20 sn \\
$\begin{array}{l}\text { GRUP IV } \\
\text { (GCP Glass }\end{array}$ & $2 \mathrm{~mm}$ & 10 & VALO LED/20 sn \\
Fill) & $1 \mathrm{~mm}$ & 10 & GCP Carbo-LED/60 sn \\
\hline
\end{tabular}




\section{Cavity preparation}

Eighty extracted, caries-free, primary molars were used in this study. The root sections of the teeth were removed approximately $2 \mathrm{~mm}$ below the cement-enamel junction and perpendicular to the long axis using a water-cooled diamond dental separating disc. The remnants of the pulp were removed with barbed broaches and an excavator, and the pulp chambers were cleaned using $5.25 \%$ sodium hypochlorite solution and distilled water. To standardize restoration, the cusps of the teeth were removed with a diamond dental separating disc to create a flat occlusal surface. The teeth were prepared as Class I occlusal cavities with surface area of $3 \times 3 \mathrm{~mm}$ and depth of $2 \mathrm{~mm}$. The remaining dentin thicknesses between the pulp chamber and cavity floor were $1 \mathrm{~mm}$ and $2 \mathrm{~mm}$ and controlled with calipers (Iwanson, Pakistan). The teeth prepared were kept wet at $+4^{\circ} \mathrm{C}$ in a physiological saline for protection from dehydration.

\section{Pulpal microcirculation model}

The pulpal microcirculation model, which was originally designed by Savas et al. (13) was used (Figure 1). Three holes were prepared on the plate to attach two pipes and a J-type thermocouple device (Elimko, Turkey). One pipe was used to carry heated water $\left(37^{\circ} \mathrm{C}\right)$ and the other was used as a drainage pipe. To facilitate temperature measurement in the finished tooth samples in cavity preparations, thermal paste (Hutixi HT-GY260, China) with very high heat conduction between $-40^{\circ} \mathrm{C}$ and $+250^{\circ} \mathrm{C}$ was injected into the pulpal floor. A flowable composite was used to attach the tooth to an acrylic plate. The fluid flow rate of the system was set and kept constant at $1 \mathrm{~mL} / \mathrm{min}$ using an infusion flowmeter (Medbar, Turkey). Distilled water at $37^{\circ} \mathrm{C}$ was used to simulate blood circulation. The thermocouple wire was linked to a data logger (EMKO PID Quadro, Turkey) and this recorded the temperature inside the pulp chamber throughout the process of light-activated curing. The procedure was repeated for all groups.

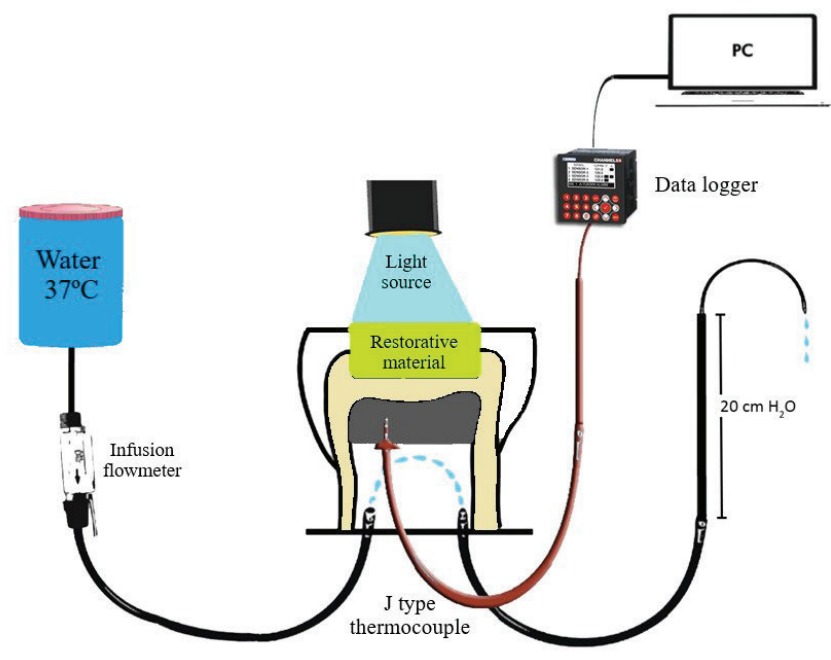

Figure 1. Schematic diagram of the measurement of intrapulpal temperature changes with pulpal microcirculation (13).
The restorative materials were filled in the cavities according to the manufacturers' instructions. Standardization of the distance between the light source and samples was achieved with the thickness of the transparent tape providing smooth surfaces for the samples. The output power of the light source was verified using a radiometer in all three samples. After the thermocouples were positioned to contact the pulp ceiling and the light sources in contact with the tooth surface, microcirculation measurements were made. The initial $\left(37^{\circ} \mathrm{C}\right)$ and peak values of temperature in the pulp chambers were measured during the process of light curing. Subsequently, the differences between the initial and highest temperature values $(\Delta t)$ were calculated.

\section{Statistical analysis}

The data obtained from our study were loaded into SPSS program for Windows (version 24.0; SPSS, Inc., Chicago, IL, USA) and one-way analysis of variance and Tukey tests were used when the parametric test assumptions were fulfilled according to the Kolmogorof-Simirnov test. The results are presented as means and standard deviations. The significance level was set to $\mathrm{p}<0.05$ for all tests.

\section{Results}

The mean maximum temperature changes and standard deviation values for all tested materials are presented in Table 4. Statistically significant differences in the recorded temperatures were observed between cavities with dentin thicknesses of $1 \mathrm{~mm}$ and $2 \mathrm{~mm}(p<0.05)$.

While there was no statistically significant difference between the temperature increases in the case of different dentin thicknesses in the Photac Fil Quick Aplicap group ( $p>0.05$ ), the temperature increases in all other groups with $1 \mathrm{~mm}$ dentin thickness were statistically significantly higher than those in groups with $2 \mathrm{~mm}$ dentin thickness $(p<0.05)$. High temperature changes were recorded in the pulp chamber when GCP Glass Fill was used on teeth with $1 \mathrm{~mm}$ and $2 \mathrm{~mm}$ dentin thicknesses $(p<0.05)$. The lowest mean temperature changes for both dentin thicknesses were seen in the Dyract XP group ( $p>0.05)$.

Table 4. Analytical and descriptive statistics of intrapulpal temperature changes in all groups

Dentin thickness

\begin{tabular}{lcccc}
\hline & \multicolumn{1}{c}{$\mathbf{1} \mathbf{~ m m}$} & \multicolumn{2}{c}{$\mathbf{~ m m}$} \\
\hline Groups & $\mathbf{n}$ & Mean \pm SD $\left({ }^{\circ} \mathbf{C}\right)$ & $\mathbf{n}$ & Mean \pm SD $\left({ }^{\circ} \mathbf{C}\right)$ \\
\hline Dyract XP & 10 & $2.13^{\mathrm{a}, \mathrm{A}} \pm 0.45$ & 10 & $1.69^{\mathrm{c}} \pm 0.18$ \\
\cline { 1 - 3 } $\begin{array}{l}\text { Photac Fil Quick } \\
\text { Applicap }\end{array}$ & 10 & $2.19^{\mathrm{a}, \mathrm{A}} \pm 0.64$ & 10 & $1.79^{\mathrm{c}} \pm 0.17$ \\
\hline Fujı II LC & 10 & $2.27^{\mathrm{a}, \mathrm{A}} \pm 0.37$ & 10 & $1.78^{\mathrm{c}} \pm 0.17$ \\
\hline GCP Glass Fill & 10 & $4.78^{\mathrm{b}, \mathrm{A}} \pm 0.45$ & 10 & $2.99^{\mathrm{d}} \pm 0.45$ \\
\hline *p values & & & 0.001 & \\
\hline
\end{tabular}

SD: Standard Deviation. Different small letters indicate statistically significance within each column (materials) and capital letter indicates statistically significance within each rows (dentin thickness), ${ }^{*} p<0.05$. 


\section{Discussion}

Temperature increases in the pulp chamber during dental procedures can negatively affect the vitality of the pulp $(4,14)$. Many factors can contribute to this effect: type, light intensity, and exposure time of light-curing unit (LCU); thickness of remaining dentin; and contents of dental restorative materials (13). The aim of this study was to evaluate temperature changes in primary teeth pulp chambers with different dentin thicknesses during polymerization of four glass ionomer-based restorative materials.

In many in vitro studies to measure temperature increase during polymerization of resin-containing restorative materials, non-carious dentin tissues were use $(15,16)$. In the study, the crown of the tooth is required for the microcirculation mechanism used to reflect clinical conditions, and since the cavities could not be standardized when using decayed tooth, it was decided to use primary teeth with non-caries or minimal or very limited caries. In primary teeth in which the physiological process is complete, peritubular dentin matrix apposition is observed owing to occlusion over a period of about eight to nine years, and primary dentin permeability may decrease (17). Dentin tubules can be partially or completely occluded by the aposition of peritubular dentin (18). Although these structural changes are thought to affect the temperature transmitted to the pulp chamber, young non-caries primary teeth cannot be obtained within the code of ethics, and hence their physiological processes were completed, root resorption was limited to the root region, and the primary teeth were used.

In studies evaluating the effects of temperature increase on dental pulp, different types of equipment were used for temperature measurement. These include calorimeters, thermocouples, differential thermal analysis, and infrared cameras (19). Studies in this field state that it is appropriate to use thermocouples in measurements because they produce reliable and sensitive results in the case of temperature changes $(13,20)$. In line with this information and its applicability to our experimental set-up, we decided to use a J-type thermocouple in our study.

Pulp microcirculation is an important factor in regulating intrapulpal temperature when heat is transferred from an external thermal stimulus to the dentine pulp complex (21). Some studies in the literature investigated the role of pulpal microcirculation in the response of pulp dentin complex to heat and reported that pulpal microcirculation acted as a refrigerant $(21,22)$. Kodonas et al. (23); evaluated temperature increases under different types of light sources with and without a microcirculation set-up. They reported that temperature increases were lower than $6^{\circ} \mathrm{C}$ in all samples when the set-up mimicking pulpal microcirculation was used. On the contrary, temperature increases exceeded $6^{\circ} \mathrm{C}$ in all samples devoid of the pulpal microcirculation set-up under all light sources except the halogen light device. Despite the attempt to mimic pulpal microcirculation in this in vitro study, the authors reported that the study did not exactly mimic in vivo conditions because it neglected the regulatory role of the pulpal nervous system, changes in pulpal blood flow, and fluid movement in dentin tubules and dentin pulp complex. Accordingly, since the cooling effect of pulp cannot be ignored, we decided to use a microcirculation mechanism in our study. As stated, there are deficiencies in the previous studies that we considered, but these conditions cannot be simulated in vitro $(20,23)$. For our study, we preferred to mechanism used by Savas et al.(13) simulated pulpal microcirculation. In the modified mechanism, the initial temperature was changed to $37^{\circ} \mathrm{C}$ to mimic body temperature and the fluid flow rate of the system was set and kept constant at $1 \mathrm{~mL} / \mathrm{min}$ using an infusion flowmeter instead of the digital infusion flow meter.

The type and duration of light application during polymerization is the most important factor in temperature increase (24). The Carbo-LED lamp LCU has been developed for thermal polymerization to optimize the properties of GC products (12). However, the data show that the use of the Carbo-LED lamp LCU results in an exothermic reaction that increases the temperature of the pulp tissue and thus increases the risk of pulpal damage $(25,26)$. In our study, the highest temperature increase among the materials used was found in the GCP Glass Fill group, but these values were not at levels that would cause pulpal damage. We considered that these high temperature changes can be caused by high light output power and long irradiation time.

In the literature, it has been reported that dentin thickness is an important factor in decreasing thermal conduction to pulpal tissues, and histological studies have established that the formation of burn lesions in pulp is observed if the remaining dentin thickness is less than $1 \mathrm{~mm}$ (27). Therefore, in our study, to examine the amount of temperature transmitted to pulp under different dentin thicknesses, the same restorative material was examined using samples with dentin thicknesses of $1 \mathrm{~mm}$ and $2 \mathrm{~mm}$.

The first hypothesis of the study was rejected. The temperature increase in the GCP Glass Fill group was found to be significantly higher than those in the other groups $(p<0.05)$. The second hypothesis of the study was accepted. In this study, there are two different dentin thicknesses; the temperature increases in groups with $1 \mathrm{~mm}$ dentin thickness were found to be statistically significantly higher than those in groups with $2 \mathrm{~mm}$ dentin thickness $(p<0.05)$.

Takahashi et al.(28) argued that remaining dentin thickness may be more important than the type and thermal spread of the material placed on the tooth in the transmission of heat to the pulp. Botsali et al.(26) evaluated temperature changes in pulp during polymerization of restorative materials in samples of permanent teeth with different dentin thicknesses and reported that the highest temperature increase was found in samples with dentin thickness of $1 \mathrm{~mm}$.

According to the findings of our study, although there was no statistically significant difference in the temperature increases between samples of different dentin thicknesses in the Photac Fil Quick Aplicap group ( $p>0.05$ ), in all other cases, the temperature increases in samples with dentin thickness of $1 \mathrm{~mm}$ were statistically significantly higher than those in samples with dentin thickness of $2 \mathrm{~mm}(p<0.05)$. We considered that a significant increase in dentin tubule number, radius, and total physical surface area for diffusion near the pulp chamber may have caused greater heat transfer to the pulp.

Zach and Cohen(4) found that an increase of $5.5^{\circ} \mathrm{C}$ in temperature caused a loss of $15 \%$ in pulp tissue vitality, and indicated this value to be a critical temperature increase. 
In our study, the temperature increases achieved did not reach the critical value of $5.5^{\circ} \mathrm{C}$.

It has been reported that temperature increases during polymerization of resin materials vary depending on the type of filler content of the restorative materials, size of filler, volume of resin matrix, and amount of organic matrix in the structure (29).

Baroudi et al. (30) and Müjdeci et al. (31) reported that the flowable composite materials had lower inorganic particle content and higher organic matrix ratio, which increased the exothermic reaction of the composite materials, resulting in higher temperature rise during polymerization.

Al-Qudah et al.(15) evaluated temperature increase during polymerization of compomer and RMGIC. They reported that RMGIC produced higher temperature increase during polymerization than that by a compomer. Additionally, they reported that RMGIC contained hydroxyethyl methacrylate (HEMA) monomer structure whereas the compomer material had urethane dimethacrylate (UDMA) and butan-1,2,3,4-tetracarboxylic acid di-2-hydroxyethylmethacrylate ester (TCB) resin monomer structures, and thus different temperature increases occurred owing to different monomer structures and amounts of materials.

Kahvecioglu et al.(32) evaluated temperature increases in pulp during polymerization of RMGIC, compomer, and GC materials in primary and permanent teeth, and reported that the lowest temperature increase occurred in the compomer group owing to its higher filler ratio and different curing mechanism than those of RMGIC.

In our study, temperature increases during polymerization in samples with different dentin thicknesses were evaluated; the highest temperature increase was found in the GCP Glass Fill group, while the lowest temperature increase was found in the Dyract XP group. While there was no statistically significant difference in temperature increases between the Fuji II LC, Photac Fil Quick Aplicap, and Dyract XP groups ( $p>0.05$ ), the temperature increases in the GCP Glass Fill groups were statistically significantly higher than those in the other groups $(p<0.05)$. The low temperature increase seen in the Dyract XP group is likely because of its high filler amount and different monomer structure, which is similar to observations made in previous studies $(15,25,30-32)$.

There are not many studies in the literature investigating temperature increases in pulp during polymerization of GC because it is a relatively new material. In addition, in accordance with the results of studies in which the GC material was examined for temperature increase $(25,26,32)$, the highest temperature increases in samples of both dentin thicknesses were obtained in the GC group but these increases did not exceed the critical value in our study. This could be the result of using Carbo-LED lamp LCU with high light output power and long irradiation time.

\section{Conclusion}

Based on the findings of our study and within its limitations (different light intensity and different curing times were used in groups, small sample size), it was concluded that the contents of restorative materials may affect the value of temperature increase that occurs during polymerization. Glass carbomer is a relatively new improved restorative material that does not contain resin, monomer, metal, and BPA. Hence, it merits a long-term follow-up study of clinical trials, the efficacy of restorations and effectiveness of remineralization activity obtained by using GC can be investigated, and the use of this material in pediatric dentistry can be considered further.

Türkçe Özet: Camiyonomer içerikli restoratif materyallerin polimerizasyonu esnasında süt dişi pulpa odasında meydana gelen sıcaklık artışı. Amaç: Cam iyonomer esaslı dört farklı restoratif materyalin polimerizasyonu sırasında, farklı dentin kalınlıklarında süt diş pulpa odasındaki sıcaklık değişimlerini değerlendirmektir. Gereç ve Yöntem: Seksen adet çekilmiş çürüksüz süt azı dişine, $1 \mathrm{~mm}$ ve $2 \mathrm{~mm}$ dentin kalınlıklarına sahip standart Sınıf I oklüzal kaviteler hazırlandı. Kavitelere cam iyonomer bazlı dört farklı restoratif materyal; Dyract XP, Photac Fil Quick Aplicap, Fuji II LC ve GCP Glass Fill yerleştirildi ve iki farklı ışık kaynağı ile polimerize edildi. Polimerizasyon sırasında pulpa odasındaki sıcaklık artışları (başlangıç sıcaklığı, $37^{\circ} \mathrm{C}$ ), pulpal mikrosirkülasyon düzeneğinde $J$ tipi bir termokupl ile kaydedildi. Veriler Varyans analizi ve Tukey testleri ile analiz edildi. Bulgular: Dentin kalınlığı $1 \mathrm{~mm}$ ve 2 $\mathrm{mm}$ olan numunelerde kaydedilen sıcaklıklar istatistiksel olarak anlamlı farklılıklar gösterdi ( $p<0.05)$. GCP Glass Fill grubu her iki dentin kalınlığı için en yüksek sıcaklık artışlarını sergiledi $(p<0.05)$. Diğer gruplar istatistiksel olarak farklı değildi, ancak Dyract XP grubu en düşük sıcaklık değişimini gösterdi. Sonuç: En yüksek sıcaklık değişiklikleri $1 \mathrm{~mm}$ dentin kalınlığı için gözlendi. Polimerizasyon ve sertleşme reaksiyonları sırasındaki tüm sıcaklık artışları, karşılık gelen kritik değer olan $5.5^{\circ}$ C'den daha düşüktü. Anahtar Kelimeler: Cam karbomer, Cam iyonomer, Süt dişi, Sıcaklık artışı, Pulpa

Ethics Committee Approval: Ethical approval was obtained from the Health Ethics Committee of Cumhuriyet University, Sivas, Turkey (ID: 2017-07/05).

Informed Consent: Participants provided informed constent.

Peer-review: Externally peer-reviewed.

Author contributions: $\mathrm{CB}$ and $\mathrm{AK}$ designed the study. $\mathrm{CB}$ participated in generating the data for the study AK participated in gathering the data for the study. $C B$ and $A K$ participated in the analysis of the data. $C B$ wrote the majority of the original draft of the paper. $C B$ and AK participated in writing the paper. All authors approved the final version of this paper.

Conflict of Interest: Authors declared no conflict of interest.

Financial Disclosure: This work was supported by the Scientific Research Project Fund Sivas Cumhuriyet University [Grant number DIS-204].

Acknowledgements: The authors thank to Dr Ziynet Cinar for her assistance with the statistical analysis.

\section{References}

1. Öztürk B, Üşümez A, Öztürk AN, Ozer F. In vitro assessment of temperature change in the pulp chamber during cavity preparation. J Prosthet Dent 2004;91:436-40. [CrossRef]

2. Schneider L, Consani S, Correr-Sobrinho L, Correr A, Sinhoreti M. Halogen and LED light curing of composite: Temperature increase and Knoop hardness. Clin Oral Investig 2006;10:66-71. [CrossRef]

3. Al-Qudah A, Mitchell C, Biagioni P, Hussey D. Effect of composite shade, increment thickness and curing light on temperature rise during photocuring. J Dent 2007;35:238-45. [CrossRef]

4. Zach L, Cohen G. Pulp response to externally applied heat. Oral Surg Oral Med Oral Pathol 1965;19:515-30. [CrossRef] 
5. Agematsu H, Abe S, Shiozaki K, Usami A, Ogata S, Suzuki K, Soejima M, Ohnishi M, Nonami K, Ide Y. Relationship between large tubules and dentin caries in human deciduous tooth. Bull Tokyo Dent Coll 2005;46:7-15. [CrossRef]

6. Paghdiwala A, Vaidyanathan T, Paghdiwala M. Evaluation of erbium: YAG laser radiation of hard dental tissues: Analysis of temperature changes, depth of cuts and structural effects. Scanning microsc 1993;7:989-97.

7. Maruo IT, Godoy-Bezerra J, Saga AY, Tanaka OM, Maruo H, Camargo ES. Effect of etching and light-curing time on the shear bond strength of a resin-modified glass ionomer cement. Brazilian dental journal 2010;21:533-7. [CrossRef]

8. Fajen VB, Duncanson MG, Jr., Nanda RS, Currier GF, Angolkar PV. An in vitro evaluation of bond strength of three glass ionomer cements. American journal of orthodontics and dentofacial orthopedics : official publication of the American Association of Orthodontists, its constituent societies, and the American Board of Orthodontics 1990;97:316-22. [CrossRef]

9. Pereira LC, Nunes MC, Dibb RG, Powers JM, Roulet JF, Navarro MF. Mechanical properties and bond strength of glass-ionomer cements. The journal of adhesive dentistry 2002;4:73-80.

10. Horváth A, Papp Z, Dobó-Nagy C, Gera I. Clinical examination of the gingival effects of three glass ionomer restorative materials (GC fuji IX GP, GC fuji IX GP EXTRA és GC EQUIA). Fogorvosi szemle 2014;107:125-30.

11. Koenraads H, Van der Kroon G, Frencken J. Compressive strength of two newly developed glass-ionomer materials for use with the Atraumatic Restorative Treatment (ART) approach in class II cavities. Dent Mater 2009;25:551-6. [CrossRef]

12. Menne-Happ U, Ilie N. Effect of gloss and heat on the mechanical behaviour of a glass carbomer cement. J Dent 2013;41:223-30. [CrossRef]

13. Savas S, Botsali MS, Kucukyilmaz E, Sari T. Evaluation of temperature changes in the pulp chamber during polymerization of light-cured pulp-capping materials by using a VALO LED light curing unit at different curing distances. Dent Mater 2014;33:764-9. [CrossRef]

14. Gavic L, Gorseta K, Glavina D, Czarnecka B, Nicholson JW. Heat transfer properties and thermal cure of glass-ionomer dental cements. J Mater Sci Mater Med 2015;26:249. [CrossRef]

15. Al-Qudah A, Mitchell C, Biagioni P, Hussey D. Thermographic investigation of contemporary resin-containing dental materials. J Dent 2005;33:593-602. [CrossRef]

16. Ozturk B, Ozturk A, Usumez A, Usumez S, Ozer F. Temperature rise during adhesive and resin composite polymerization with various light curing sources. Oper Dent 2004;29:325-32.

17. Koutsi V, Noonan R, Horner J, Simpson M, Matthews W, Pashley $\mathrm{DH}$. The effect of dentin depth on the permeability and ultrastructure of primary molars. Pediatr Dent 1994;16:29-35.

18. Mjör P. Dentin-predentin complex and its permeability: Pathology and treatment overview. J Dent Res 1985;64:621-7. [CrossRef]
19. Guiraldo RD, Consani S, Lympius T, Schneider LF, Sinhoreti MA, Correr-Sobrinho L. Influence of the light curing unit and thickness of residual dentin on generation of heat during composite photoactivation. J Oral Sci 2008;50:137-42. [CrossRef]

20. Ramoglu SI, Karamehmetoglu H, Sari T, Usumez S. Temperature rise caused in the pulp chamber under simulated intrapulpal microcirculation with different light-curing modes. Angle Orthod 2015;85:381-5. [CrossRef]

21. Kodonas K, Gogos C, Tziafas D. Effect of simulated pulpal microcirculation on intrapulpal temperature changes following application of heat on tooth surfaces. Int Endod J 2009;42:24752. [CrossRef]

22. Michalakis K, Pissiotis A, Hirayama H, Kang K, Kafantaris N. Comparison of temperature increase in the pulp chamber during the polymerization of materials used for the direct fabrication of provisional restorations. J Prosthet Dent 2006;96:418-23. [CrossRef]

23. Kodonas K, Gogos C, Tziafa C. Effect of simulated pulpal microcirculation on intrachamber temperature changes following application of various curing units on tooth surface. J Dent 2009;37:485-90. [CrossRef]

24. Carrasco TG, Carrasco-Guerisoli LD, Fröner IC. In vitro study of the pulp chamber temperature rise during light-activated bleaching. J Appl Oral Sci 2008;16:355-9. [CrossRef]

25. Altan H, Göztas Z, Arslanoglu Z. Bulk-Fill restorative materials in primary tooth: An intrapulpal temperature changes study. Contemp Clin Dent 2018;9:52-7. [CrossRef]

26. Botsali MS, Tokay U, Ozmen B, Cortcu M, Koyuturk AE, Kahvecioglu F. Effect of new innovative restorative carbomised glass cement on intrapulpal temperature rise: an ex-vivo study. Braz Oral Res 2016;30. [CrossRef]

27. Loney R, Price R. Temperature transmission of high-output lightcuring units through dentin. Oper Dent 2001;26:516-20.

28. Takahashi N, Kitagami T, Komori T. Evaluation of thermal change in pulp chamber. J Dent Res 1977;56:1480. [CrossRef]

29. Hubbezoglu I, Dogan A, Dogan O, Demir H. Kompozit rezin materyallerin farkli ışık kaynaklarıyla polimerizasyonu sırasında oluşan ısısal değişikliklerin incelenmesi. Cumhuriyet Dent J 2008;11:16-22.

30. Baroudi K, Silikas N, Watts DC. In vitro pulp chamber temperature rise from irradiation and exotherm of flowable composites. Int J Paediatr Dent 2009;19:48-54. [CrossRef]

31. Müjdeci A, Yeşilyurt A, Gökay O. Kompozit rezinlerin polimerizasyonları esnasında pulpa odasındaki ısı değişimlerinin in vitro değerlendirilmesi. AÜ Diş Hek Fak Derg 2005;32:163-9. [CrossRef]

32. Kahvecioglu F, Tosun G, Ülker HE. Intrapulpal thermal changes during setting reaction of glass Carbomer ${ }^{\circledR}$ using thermocure lamp. Biomed Res Int 2016:1-7. [CrossRef] 